\title{
Comparison of Students' Reasoning Skills between 'Numbered Head Together' and 'Think Pair Share' Based on Portfolio
}

\author{
Via Yustitia ${ }^{1}$ \\ ${ }^{1}$ Adi Buana PGRI University of Surabaya \\ Email : yustitia.via@gmail.com
}

\begin{abstract}
Student reasoning skills for students are very significant to develop in solving the mathematics problem. Several ways to improve the ability of Mathematics reasoning is through NHT and TPS. The purposes of this study were to find out the average competence of student's reasoning skills between the Numbered Head Together (NHT) and Think Pair Share (TPS) based on portfolio. The population of this study was students of the elementary school teacher education department of Adi Buana PGRI University of Surabaya, by using Cluster Random Sampling. The data was collected by using test method. The data analyses were (1) T test of right side, to examine the level of individual minimum score completeness; (2) $\mathrm{Z}$ test, to examine the level of classical minimum score completeness; (3) $\mathrm{T}$ test the difference of average, to examine the distinction of reasoning skills between the NHT and TPS class. The result of the study showed that: (1) NHT class based portfolio had already passed the minimum score although the students of experiment class; (2) TPS class based portfolio had already passed the minimum score although the students of experiment class; (3) score average of the student's reasoning skills in TPS class were better than score average of the student's reasoning skills in NHT class.
\end{abstract}

Keywords: Numbered Head Together; Portfolio; Reasoning Skills; Think Pair Share

\section{INTRODUCTION}

Mathematics is an excellent vehicle for the development and improvement of a person's intellectual competence in logical reasoning, spatial visualization, analysis, and abstract thought. When reasoning skills of the students not developed, then for students of mathematics will only be a matter of following a series of procedures and imitate the examples without knowing its interpretation. The reasoning is thoughts adopted to produce the statement and reached the conclusion on troubleshooting issues that are not always based on formal logic that is not limited to the evidence [1].

The reasoning of indicators must be achieved by the students (Wardhani,2008): (1) the ability to render mathematics statement orally, written, pictures and diagrams, (2) the ability to ask suspected, (3) the capability to perform the manipulation of mathematics, (4) the ability to arrange the evidence gives the reason /evidence against the truth of the solution, (5) the ability to draw conclusions from the 
statement, (6) checks the validity of a arguments, (7) Find the pattern or nature of the mathematical symptoms to make generalizations.

Based on the result of observation researchers, it is known that students had difficulty in solving the question of reasoning. As student difficulties in completing the questions the reasoning of mathematics. As much as $42,15 \%$ learning mathematical concepts courses 2015/2016 school year students have not yet reached passed the minimum score. The implementation of teaching in the state is still teacher center. Learning activities learners not good, this can be observed with only $20 \%$ learners are asked during the learning process.

The lecturer should be able to make the students alter the pattern of learning which tend to receive to become more active in learning so that students can use the logic. Lecturers need to pay attention to the model of teaching which is used to achieve the goal of the development of the ability to reason. Cooperative Learning in mathematics will be able to help learners build confidence toward its ability to solve mathematics problems. Cooperative learning allows students to process new information and, through discussion and peer to peer interaction, assign meaning to what is being learned [2]. Some of the cooperative learning models are the NHT and TPS learning models.

Numbered Head Together is a method of learning and group discussion conducted with how to give the number to all learners and quiz or task to discuss the answers or troubleshooting in the group. Nasrun [3] concluded that the application of learning models Number Head Together has a role in improving student learning outcomes. Think pair share is a strategy that is used for teaching speaking. It includes three phases: thinking phase (individual work), discussing phase (pair work) and sharing phase (group work) [4]. Research Results Utami shows that the mathematical reasoning ability students who use the learning TPS better than on mathematical reasoning ability students who use conventional learning. Raba [4] claimed that TPS application in the classroom has helped them think and organize their thoughts.

Portfolios are perceived to be very helpful in the learning process because the portfolio is a bundle of the results of the paper as a result of the implementation of the task, performance as part of the learning goal or to achieve the competencies which is determined by the curriculum. From the explanation above, learning NHT and TPS which are both based on the portfolio in accordance with the theory about learning constructivism.

Based from the explanation above, author wants to do research with the foreground lessons the title of "Comparison Students Reasoning Skills between the Numbered Head Together and Think Pair Share Based on Portfolio". The purposes of this study were to find out the average competence of student's reasoning skills between the Numbered Head Together (NHT) and Think Pair Share (TPS) based on portfolio.

\section{METHODOLOGY}

This research was quantitative. It was conducted from March 7 until July 16, 2017. It was held in primary school teacher education department (PGSD) of Adi Buana PGRI University, Surabaya. The population of this study was students of the elementary school teacher education department of University of PGRI Adi Buana 
Surabaya, by using Cluster Random Sampling. It was divided into two classes, Class $\mathrm{C}$ as the class experiment 1 and Class B as a class experiment 2.

The research design this experiment used Quasi Experimental Design with the form of posttest only control design. The design of the experiment can be seen in the table 1, as follow:

Table I. The design of the experiment

\begin{tabular}{|l|l|l|l|}
\hline & group & treatment & Post-Test \\
\hline Random & experiment 1 & $\mathrm{X} 1$ & $\mathrm{~T}$ \\
Random & experiment 2 & $\underline{\text { X2 }}$ & T \\
\hline
\end{tabular}

The variables used in this research were the dependent variables and independent variables. The independent variable was NHT and TPS models, while the dependent variable was the ability of the reasoning. The data collected by using test method. The data analyses were using: (1) $\mathrm{T}$ test of right side, to examine the level of individual minimum score completeness; (2) $\mathrm{Z}$ test, to examine the level of classical minimum score completeness; (3) $\mathrm{T}$ test the difference of average, to examine the distinction of reasoning skills between the Numbered Head Together and Think Pair Share class.

\section{RESULT AND DISCUSSION}

According to the data analysis in the early stages with the normality test obtained the normal data. Based on the analysis of the data during the early stages of using the test of homogeneity, and the average similarity tests showed that the class was taken as the samples in research. It had variants homogenous and did not have the average differences. This means that the sample was derived from the condition or state of the beginning of the relative is not different from that have the same knowledge.

After given preferential treatment in the class samples, the writer obtained an average test capabilities result toward students' logic in the class who incur NHT and learning classes of the subject of learning the TPS. The result can be seen in the table 2 as follow;

Table II. Descriptive Statistics

\begin{tabular}{|l|r|r|r|r|r|}
\hline & $\mathrm{N}$ & Minimum & Maximum & \multicolumn{1}{c|}{ Mean } & \multicolumn{1}{c|}{ Std. Deviation } \\
\hline eks1_NHT & 30 & 45.00 & 90.00 & 72.2000 & 10.53205 \\
eks2_TPS & 30 & 54.00 & 88.00 & 73.7667 & 9.19776 \\
Valid N (listwise) & 30 & & & & \\
\hline
\end{tabular}

The results of the data analysis value at the end of the students class experiment 1 shows the average value of 72.20 students were able to achieve the criteria of learning in line with the specified minimum school of 70 . From the test results, it was obtained proportion of the number of students who achieve minimum score completeness as much as 80 percent or more than 75 percent and the value of the word yet so that it can be done in the classroom learning experiment 1 achieve learning in line with the classical period according to the criteria specified by the school. So it could be concluded that students who use the learning portfolio based NHT had reached the learning in line with the individually and classical. 
The results of the data analysis value at the end of the students of class experiment 1 shows the average value of 73.76 students were able to achieve the criteria of learning in line with the specified minimum school of 70 . From the test results, it was obtained proportion of the number of students who achieve minimum score completeness as much as 84 percent or more than 75 percent and the value of the word yet so that it can be done in the classroom learning experiment 1 achieve learning in line with the classical period according to the criteria specified by the school. So it could be concluded that students who use the learning portfolio based NHT has reached the learning in line with the individually and classical.

TPS was applied in class experiment effectively against the ability of the logic. Based on the calculation of the average similarity tests one party (test the right) obtained $t$ count $=2.805$ and $t=1.665$ table. Because $t$ count $>t$ the table then $\mathrm{H} 0$ rejected, it means that the average ability of the logic of the students of class experiment 1 was better than the class experiment 2 .

TPS makes the students having the opportunity to participate actively so that students can get a better understanding. Based on the opinion of cooperative learning model the type of Think Pair Share (TPS) allows the involvement of all students actively in the learning process that gives a positive impact to the development of the mathematical reasoning ability students. This is in accordance with the opinion of Lie [5], cooperative Learning model the type of Think Pair Share (TPS) is one of the types of cooperative learning model that give the opportunity for each student to show the participation to other people. This is also in accordance with the results of research Ike Natalliasari [6], there are different capacity of mathematical reasoning students who get use learning model of cooperative learning the type of Think Pair Share (TPS) with students who get conventional learning

Stages in the NHT force students to discuss, communicate and appreciate the opinion of his neighbor, argued between members of the group to obtain a conclusion. However, class tends to many, if a lecturer cannot manage the class well, the noise cannot be controlled. Not all the students involved in learning. Not all the members of the group are called by the lecturer, called students with a certain number only. This is also in accordance with the results of research Yenni [7] shows that NHT not fully can improve the ability of the reasoning of the students.

The results of the study showed that the selection of appropriate learning model can give a positive contribution to the ability of the logic of the students. The learning model can create a climate that supports the potential and interests of the students so that the teaching be successful.

\section{CONCLUSION}

The result of the study showed that: (1) Numbered Head Together class base portfolio had already passed the minimum score although the students of experiment class; (2) Think Pair Share class based portfolio had already passed the minimum score although the students of experiment class; (3) score average of the student's reasoning skills in Think Pair Share class were better than score average of the student's reasoning skills in Numbered Head Together class. 


\section{REFERENCES}

[1] Lithner, J. 2008. A Research Framework for Creative and Imitative Reasoning. Education Study Mathematic, vol. 6, no. 67, hlm 255-276.

[2] Lujan, H., \& DiCarlo, S. E. (2005). Too much teaching, not enough learning: what is the solution?. Advances in Physiology Education, vol. 30, no. 1, hlm 17-22.

[3] Nasrun. 2016. The Use of Cooperative Learning With Number Head Together Model to Improve the Students' Mathematics Subject. IOSR Journal of Mathematics, vol. 12, no. 5, hlm 113-117.

[4] Raba, A, A, A. 2017. The Influence of Think-Pair-Share (TPS) on Improving Students' Oral Communication Skills in EFL Classrooms. Creative Education. Vol. 8, hlm 12-23.

[5] Lie, Anita. 2004. Kooperatif learning. Jakarta : PT Grasindo.

[6] Ike Natalliasari. 2015. Meningkatkan Kemampuan Penalaran Matematis Siswa MTs Melalui Penerapan Model Pembelajaran Kooperatif Tipe Think Pair Share. Jurnal Penelitian Pendidikan dan Pengajaran Matematika. vol. 1, no. 1, hlm 33-40.

[7] Yenni. 2016. Analisis Kemampuan Penalaran Matematis Siswa SMP Melalui Model Pembelajaran Numbered Heads Together. Jurnal Prima. vol. 5, no. 2, hlm 73-81.

[8] Shadiq, F. (2009). Kemahiran Matematika. [Online]. Tersedia: https://mgmp-matsatapmalang.file.word-press.com/2011/11/smalanjutkemahiran-fadjar.pdf [diakses pada tanggal 29 November 2016]. 